Article

\title{
Comparison of Electrochemical Methods for the Evaluation of Cast AZ91 Magnesium Alloy
}

\author{
Jakub Tkacz ${ }^{1, *}$, Jozef Minda ${ }^{1}$, Stanislava Fintová ${ }^{1,2}$ and Jaromír Wasserbauer ${ }^{1}$ \\ 1 Materials Research Centre, Faculty of Chemistry, Brno University of Technology, Brno 612 00, \\ Czech Republic; xcminda@fch.vut.cz (J.M.); fintova@ipm.cz (S.F.); wasserbauer@fch.vut.cz (J.W.) \\ 2 Institute of Physics of Materials, Academy of Sciences of the Czech Republic v. v. i., Žižkova 22, \\ Brno 616 62, Czech Republic \\ * Correspondence: tkacz@fch.vut.cz; Tel.: +420-54-114-9469
}

Academic Editor: Regine Willumeit-Römer

Received: 15 September 2016; Accepted: 10 November 2016; Published: 15 November 2016

\begin{abstract}
Linear polarization is a potentiodynamic method used for electrochemical characterization of materials. Obtained values of corrosion potential and corrosion current density offer information about material behavior in corrosion environments from the thermodynamic and kinetic points of view, respectively. The present study offers a comparison of applications of the linear polarization method (from $-100 \mathrm{mV}$ to $+200 \mathrm{mV}$ vs. $\left.\mathrm{E}_{\mathrm{OCP}}\right)$, the cathodic polarization of the specimen $\left(-100 \mathrm{mV}\right.$ vs. $\left.\mathrm{E}_{\mathrm{OCP}}\right)$, and the anodic polarization of the specimen $\left(+100 \mathrm{mV}\right.$ vs. $\left.\mathrm{E}_{\mathrm{OCP}}\right)$, and a discussion of the differences in the obtained values of the electrochemical characteristics of cast AZ91 magnesium alloy. The corrosion current density obtained by cathodic polarization was similar to the corrosion current density obtained by linear polarization, while a lower value was obtained by anodic polarization. Signs of corrosion attack were observed only in the case of linear polarization including cathodic and anodic polarization of the specimen.
\end{abstract}

Keywords: AZ91 magnesium alloy; cathodic polarization curve; anodic polarization curve; linear polarization curve

\section{Introduction}

Magnesium alloys are used in automotive and aerospace industries, as well as in computers, cell phones, sports equipment, and for many other applications. The wide range of applications of magnesium alloys is due to the good strength to weight ratio, good mechanical properties, and low density [1-8]. The possibility to tailor the material properties by changing the chemical composition and adequate mechanical and chemical treatment is also important. Many magnesium alloys are also promising to be used as biodegradable materials for medical applications [9-33]. Magnesium is nontoxic and biocompatible [15,19,21,34,35]. Magnesium ions also have very important biological functions; for example, magnesium takes part in bone and mineral homeostasis [29,36-38], promoting DNA replication and transcription [29,37,39], and regulation of opening and closing of ion channels $[29,37,38,40-42]$. When magnesium implants are used for bone support, they also supports the bone tissue to grow $[29,43]$.

The high reactivity of magnesium and its alloys in a corrosion environment, especially in $\mathrm{Cl}^{-}$ solutions, limits their application in the engineering practice and also for medical applications. If the magnesium-based implant corrodes too fast (corrosion rate is too high), new bone tissue cannot replace already-corroded implant parts. The supporting effect of the implant and the advantage of similar strength and modulus of the magnesium-based materials to human bone is lost $[9,29,43-48]$. The corrosion of magnesium alloys is also accompanied by hydrogen evolution and intense alkalization 
of the surrounding tissues, which is a problem not only for orthopedic implants but also for cardiovascular stents $[9,49]$.

Corrosion resistance of magnesium alloys and their corrosion rate can be basically affected by the chemical composition of the alloy (especially by controlling the impurities, such as Fe and $\mathrm{Cu}$ ), mechanical or thermal treatment (with the aim to reach a homogeneous microstructure or to obtain a microstructure that controls the corrosion attack), or by surface treatment, especially coating (conversion, ceramic, etc.) [9,29,50-62].

AZ group magnesium alloy enhanced corrosion properties are reached due to the content of $\mathrm{Al}$ in the solid solution and is even improved by the addition of $\mathrm{Zn}$. Content of $\mathrm{Al}$ also influences the amount of $\mathrm{Mg}_{17} \mathrm{Al}_{12}$ intermetallic phase particles, which affects the corrosion processes. The influence of $\mathrm{Mg}_{17} \mathrm{Al}_{12}$ particles on the alloy corrosion properties depends on their amount, morphology, and distribution in the alloy structure. In the case of cast alloys, the phase present in the eutectic form act as a barrier against corrosion propagation through the solid solution (lower corrosion resistance comparing to the intermetallic phase) and retard the corrosion evolution. However, the present intermetallic particles can also act as the cathode in microgalvanic cells and accelerate the corrosion process. This was observed in the case of material after mechanical treatment, where the $\mathrm{Mg}_{17} \mathrm{Al}_{12}$ intermetallic phase was present in the structure in the form of small localized particles. On the other hand, in the case of a homogenous distribution of very fine $\mathrm{Mg}_{17} \mathrm{Al}_{12}$ particles in magnesium alloy structure, a positive influence on the corrosion behavior can be reached. Very fine structure of AZ magnesium alloys reached after severe plastic deformation treatment had positive influence on the alloy corrosion properties due to the uniform corrosion of the alloy surface and protection of the material against the contact with the corrosion environment via the created corrosion products covering the whole surface. In addition to the present intermetallic phases, the grain boundaries, which are normally cathodic compared with the body of the grains, also influence the corrosion attack evolution [63-68].

Corrosion behavior of magnesium alloys can be analyzed by several methods. The methods can be basically divided into: (i) short-term methods (electrochemical methods, such as potentiodynamic polarization or electrochemical impedance spectroscopy); and (ii) longer term methods (such as mass loss or hydrogen gas collection). Both types of the methods have their specifics and the obtained data have to be interpreted carefully. Data obtained by the short-term methods may not be indicative of long-term corrosion, while the material reactions in the corrosive environment change with the exposure time (a protective layer is created, broken, recreated, etc.). The data obtained during the long-term experiments have to take into account the experiment conditions; especially the duration of the experiment has to be set precisely. Depending on the used method the determined corrosion rates of magnesium and its alloys can differ. Corrosion rates estimated based on the results obtained by electrochemical methods are usually lower when compared to the other methods, which is a result of changing the corrosion rate of the material in time due to the changing reactivity of magnesium due to the changing $\mathrm{pH}$ on the surface [69].

The advantage of electrochemical methods is in the continuous monitoring of the corrosion process during the relatively short exposure time. However, electrochemical methods can only follow corrosive process due to electrochemical dissolution. When other chemical reactions participate in the corrosion process, corrosion rates determined based on electrochemical method results might be much lower compared to the values determined by weight loss measurements, volume of hydrogen gas, or amount of corrosion products in the solution. The differences in the determined values depend on the corrosion behavior of the exact material and also change in the case of different alloys due to the chemical composition. Pardo et al. [68] showed good agreement in the corrosion rates estimated by electrochemical methods and mass loss measurements for AZ80 and AZ91D, however, different values were determined for pure Mg and AZ31 (lower values were estimated by electrochemical methods).

Potentiodynamic measurements performed via linear polarization are usually used to obtain polarization Tafel curve,s from which the corrosion potential $\left(\mathrm{E}_{\mathrm{corr}}\right)$ and the corrosion current density 
$\left(\mathrm{i}_{\text {corr }}\right)$ can be determined. Potentiodynamic polarization shows the information about the corrosion process kineticss and it is the only method that can reveal the relative anodic and cathodic contributions. The method is destructive in nature and cannot serve for prediction of the long-term corrosion rates of the material [69].

The evaluation of the obtained polarization curves used in Tafel analysis are based on the extrapolation of the linear parts of the obtained curves. Tafel regions used for the polarization curve evaluation start at approximately $50 \mathrm{mV}$ (usually up to $100 \mathrm{mV}$ ) from the corrosion potential $\left(\mathrm{E}_{\mathrm{corr}}\right)$, and the open circuit potential $\left(\mathrm{E}_{\mathrm{OCP}}\right)$ in the steady state, in the cathodic, as well as the anodic, branches of the polarization curve. The Tafel region is characterized by linear dependence of $i_{\text {corr }}$ on $\mathrm{E}_{\mathrm{corr}}$. Figure 1 shows Tafel extrapolation of the Tafel region (linear part of the anodic branch of the polarization curve) which is used to evaluate potentiodynamic characteristics to obtain the corrosion current $\mathrm{I}_{\text {corr }}$ from which the corrosion current density $\mathrm{i}_{\text {corr }}$ can be calculated $\left(\mathrm{i}_{\text {corr }}=\mathrm{I}_{\text {corr }} /\right.$ specimen area immersed in the corrosion environment) [70,71].

For many metals and alloys exhibiting active-passive behavior, the anodic part of the polarization curve should not be used for the evaluation of material behavior because of the absence of the linear Tafel region. There are some other limitations for the Tafel analysis of the polarization curve caused by the mechanism of the corrosion process. The cathodic branch of the polarization curve cannot be used for Tafel analysis when the corrosion is under diffusion control; decreasing potential enters into the diffusion control region or the nature of the interface changes with the changing potential $[70,71]$.

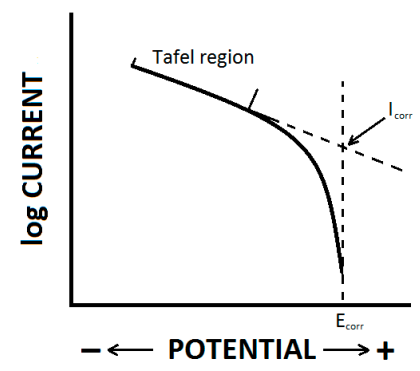

Figure 1. Tafel extrapolation of the cathodic part of the polarization curve.

For material electrochemical properties, descriptions are in the literature, as are the linear polarizations also present only in anodic or cathodic branches of the polarization curves. Anodic branches of the polarization curves were reported, for example, for the characterization of corrosion behaviors of $\mathrm{Mg}_{95} \mathrm{Al}_{3} \mathrm{Er}_{2}$ and $\mathrm{AM} 60$ as cast alloys [58] and $\mathrm{AZ91}$ [72]. Only anodic branches of the polarization curves were used for the description of the corrosion behavior of different dental alloys [73]. On the other hand, only cathodic branches of the polarization curves were compared with the mass loss test results for $\mathrm{Mg}-8 \mathrm{Sn}-1 \mathrm{Zn}-1 \mathrm{Al}$ and $\mathrm{Mg}-8 \mathrm{Sn}-1 \mathrm{Zn}-1 \mathrm{Al}-0.1 \mathrm{Mn}$ alloys in [74]. However, no comparison and interpretation of the data obtained using linear polarization, evaluating only anodic or cathodic branches of the curve, are available in the literature according to the authors' knowledge.

The present paper offers a comparison of the potentiodynamic characteristics of cast AZ91 magnesium alloy obtained by the linear polarization method (from $-100 \mathrm{mV}$ to $200 \mathrm{mV}$ vs. $\mathrm{E}_{\mathrm{OCP}}$ ), by the cathodic polarization of the specimen $\left(-100 \mathrm{mV}\right.$ vs. $\left.\mathrm{E}_{\mathrm{OCP}}\right)$, and by the anodic polarization of the specimen $\left(+100 \mathrm{mV}\right.$ vs. $\left.\mathrm{E}_{\mathrm{OCP}}\right)$. The obtained results are discussed in terms of surface corrosion attack analysis performed by scanning electron microscopy.

\section{Experimental Material and Methods}

\subsection{Material}

A rod of cast AZ91 magnesium alloy was used for the comparison of methods of linear polarization in this study. The chemical composition of the cast AZ91 magnesium alloy was given by the producer, as shown in Table 1. 
Table 1. Chemical composition of studied cast AZ91 magnesium alloy.

\begin{tabular}{cccccccccc}
\hline \multirow{2}{*}{ Alloy } & \multicolumn{10}{c}{ Chemical Composition (wt\%) } \\
\cline { 2 - 11 } & $\mathbf{A l}$ & $\mathbf{Z n}$ & $\mathbf{M n}$ & $\mathbf{S i}$ & $\mathbf{F e}$ & $\mathbf{B e}$ & $\mathbf{N i}$ & $\mathbf{C u}$ & $\mathbf{M g}$ \\
\hline AZ91 & 8.7 & 0.65 & 0.25 & 0.006 & 0.003 & 0.0008 & 0.0006 & 0.0005 & rest \\
\hline
\end{tabular}

\subsection{Microstructure Analysis}

To observe the microstructure of the examined AZ91 magnesium alloy, a specimen was cut and embedded into resin. The specimen was ground with 2500 grit SiC paper and polished by diamond paste $(1 \mu \mathrm{m})$. The polished specimen was etched by picral solution $\left(0.4 \mathrm{~g}\right.$ picric acid, $0.3 \mathrm{~cm}^{3}$ acetic acid, 0.7 distilled water, and $40 \mathrm{~cm}^{3}$ ethanol) for $10 \mathrm{~s}$. The microstructure of the AZ91 was studied by scanning electron microscope (SEM) (ZEISS EVO LS 10, Cambridge, UK) with elemental mapping mode using EDS (OXFORD INSTRUMENTS X-MAX $80 \mathrm{~mm}^{2}$, Abingdon, UK).

\subsection{Electrochemical Measurements}

Cast AZ91 magnesium alloy rod was cut into specimens with dimension of $\varnothing 15 \times 2 \mathrm{~mm}$. Before the test each specimen was ground with 1200 grit SiC paper, cleaned in acetone in an ultrasonic bath (K5 Kraintek, Hradec Králové, Czech Republic) for 5 min to remove residual impurities (grease etc.), rinsed with isopropanol, and dried by warm air. For each measurement five random specimens were prepared.

Electrochemical tests were performed by potentiostat/galvanostat BioLogic VSP-300 in $0.1 \mathrm{M}$ $\mathrm{NaCl}$ solution in a three-electrode system: AZ91 alloy was used as the working electrode, a saturated calomel electrode (SCE) as the reference electrode, and a platinum gauze as the counter electrode. All of the measurements were performed at room temperature. Stabilization time of the specimen exposed to the corrosion environment to read the value of open circuit potential $\left(\mathrm{E}_{\mathrm{OCP}}\right)$ was $5 \mathrm{~min}$. An area of the specimen exposed to the corrosion environment was $1.0 \mathrm{~cm}^{2}$. Measured data were evaluated by BioLogic EC-Lab software (V10.44, BioLogic, Claix, France).

Cathodic polarization curves (CPCs) were measured by polarizing the specimen from the open circuit potential (EOCP) to a value of $-100 \mathrm{mV}$ vs. $\mathrm{E}_{\mathrm{OCP}}$. Anodic polarization curves (APCs) were measured by polarizing the specimen surface from $\mathrm{E}_{\mathrm{OCP}}$ to a value of $+100 \mathrm{mV}$ vs. $\mathrm{E}_{\mathrm{OCP}}$. Potentiodynamic (linear) polarization curves (PCs) containing cathodic and anodic branches together were measured by polarizing the specimen surface to a range from $-100 \mathrm{mV}$ to $+200 \mathrm{mV}$ vs. $\mathrm{E}_{\mathrm{OCP}}$, [2,57], to ensure the Tafel region on the anodic branch of the PC. The scan rate was $1 \mathrm{mV} \cdot \mathrm{s}^{-1}$. All of the polarization curves were evaluated by Tafel extrapolation (Figure 1 ) of Tafel regions to obtain $\mathrm{i}_{\text {corr }}$.

\section{Results}

\subsection{Microstructural Analysis}

The microstructure of cast AZ91 magnesium alloy is shown in Figure 2a. The microstructure of the alloy consists of $\alpha-\mathrm{Mg}$ areas (solid solution of alloying elements in magnesium), $\beta$ phase $\left(\mathrm{Mg}_{17} \mathrm{Al}_{12}\right.$ intermetallic phase), $\mathrm{Mg}-\mathrm{Al}$ discontinuous precipitate, and $\mathrm{Al}-\mathrm{Mn}$ based intermetallic particles.

The distribution of basic alloying elements and present phases was verified by EDS analysis and is presented in a form of elemental maps in Figure $2 \mathrm{~b}-\mathrm{e}$. 


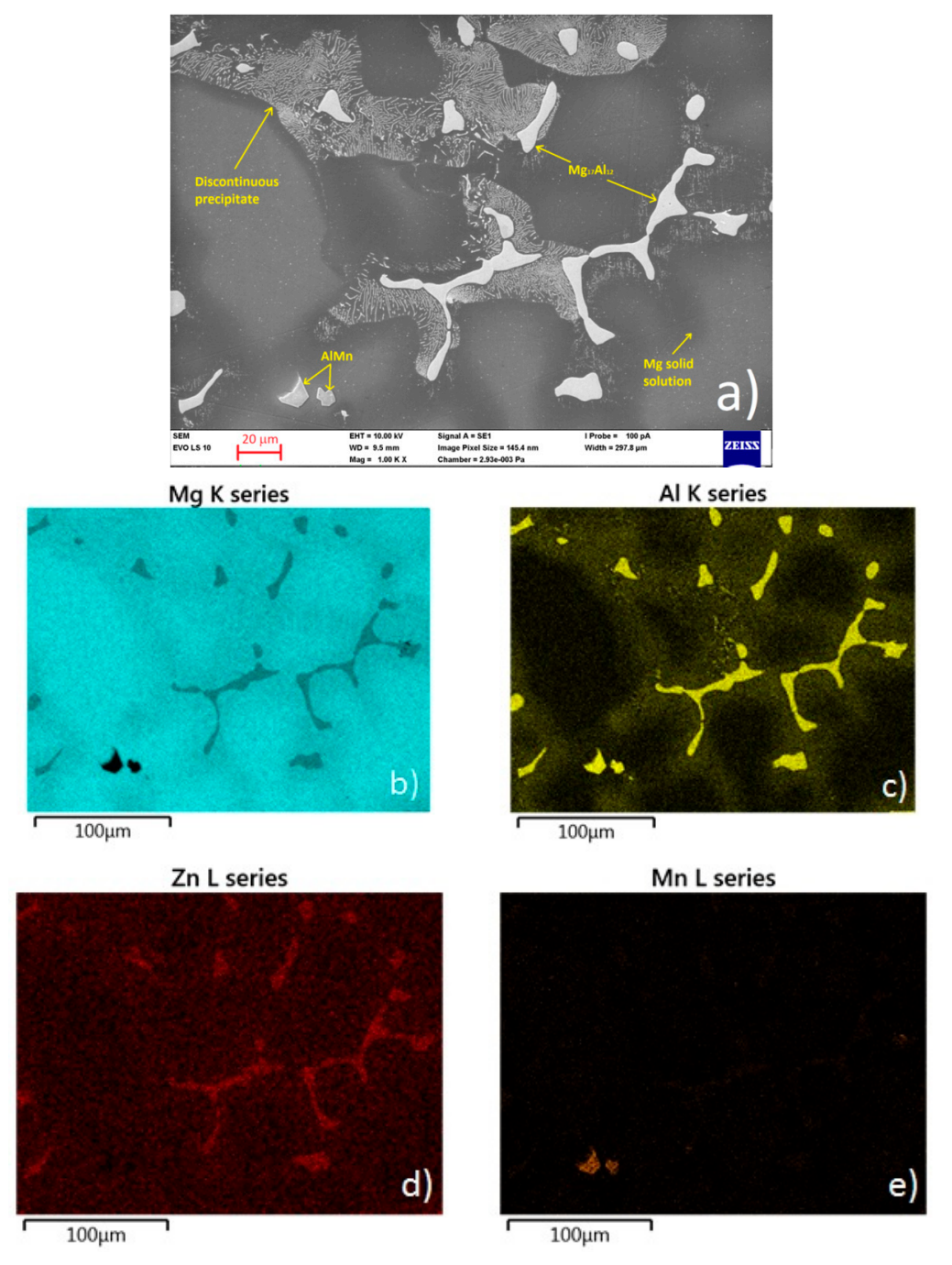

Figure 2. Microstructure of AZ91 magnesium alloy (a) and elemental maps: (b) magnesium; (c) aluminum; (d) zinc; and (e) manganese (SEM).

\subsection{Linear Polarization Measurements}

Three different methods of linear polarization were applied to obtain corrosion potential and corrosion current density of the examined cast AZ91 alloy.

Figure 3 shows CPCs measured by polarization of the specimen to the cathodic region (cathodic polarization; $-100 \mathrm{mV}$ vs. $\mathrm{E}_{\mathrm{OCP}}$ ). In these conditions hydrogen depolarization occurs on the specimen surface observed via the hydrogen bubble formation. The Tafel region, with a size of approximately $50 \mathrm{mV}$ from the corrosion potential $\left(\mathrm{E}_{\mathrm{corr}}\right)$, was used for the data extrapolation, Figure 1 , to obtain the corrosion current density $i_{\text {corr }}$. The average value of the corrosion current density from the CPCs obtained from five specimens (Table 2) was $15.4 \pm 1.0 \mu \mathrm{A} \cdot \mathrm{cm}^{-2}$. 


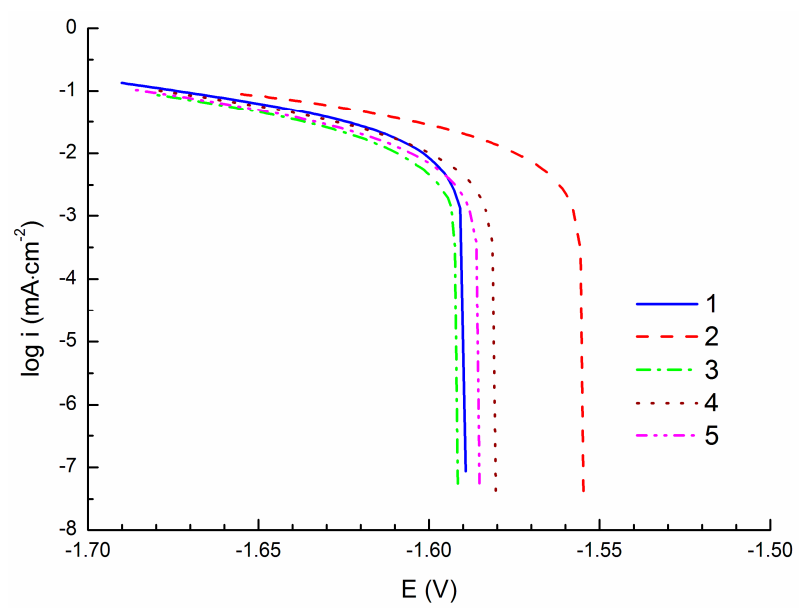

Figure 3. Cathodic polarization curves (CPCs) of AZ91 tested in $0.1 \mathrm{M} \mathrm{NaCl}$ solution; $-100 \mathrm{mV}$ vs. $\mathrm{E}_{\mathrm{OCP}}$.

Table 2. Electrochemical characteristics of AZ91 in $0.1 \mathrm{M} \mathrm{NaCl}$ solution determined by cathodic polarization.

\begin{tabular}{cccccc}
\hline Sample & $\mathbf{1}$ & $\mathbf{2}$ & $\mathbf{3}$ & $\mathbf{4}$ & $\mathbf{5}$ \\
\hline EOCP $(\mathrm{V})$ & -1.585 & -1.555 & -1.585 & -1.579 & -1.580 \\
Range of Tafel region $(\mathrm{mV})$ & $\sim 50$ & $\sim 50$ & $\sim 50$ & $\sim 50$ & $\sim 50$ \\
$\mathrm{i}_{\text {corr }}\left(\mu \mathrm{A} \cdot \mathrm{cm}^{-2}\right)$ & 15.0 & 14.2 & 16.5 & 14.5 & 16.7 \\
\hline
\end{tabular}

Measured APCs are shown in Figure 4. The curves were measured by polarization specimen to the anodic region (anodic polarization; $+100 \mathrm{mV}$ vs. EOCP). In these conditions oxidation (corrosion) of the magnesium alloy occurs. At the end of the curves non-linear regions are observed. This could indicate the beginning of pitting corrosion [75]. With respect to this fact was a potential at the beginning of the non-linear region determined as pitting potential $\mathrm{E}_{\text {pit }}$. The range of the Tafel region used for the curves' extrapolation and corrosion current density determination was not of $50 \mathrm{mV}$ (length sufficient for curve extrapolation according to the literature $[63,64]$ ), however, the extrapolation was performed on sufficient parts of the curves and the obtained data are given in Table 3 . The average value of $\mathrm{E}_{\mathrm{OCP}}$ determined from APCs was $-1.582 \pm 0.004 \mathrm{~V}$ and the corrosion current density was of $8.0 \pm 0.6 \mu \mathrm{A} \cdot \mathrm{cm}^{-2}$.

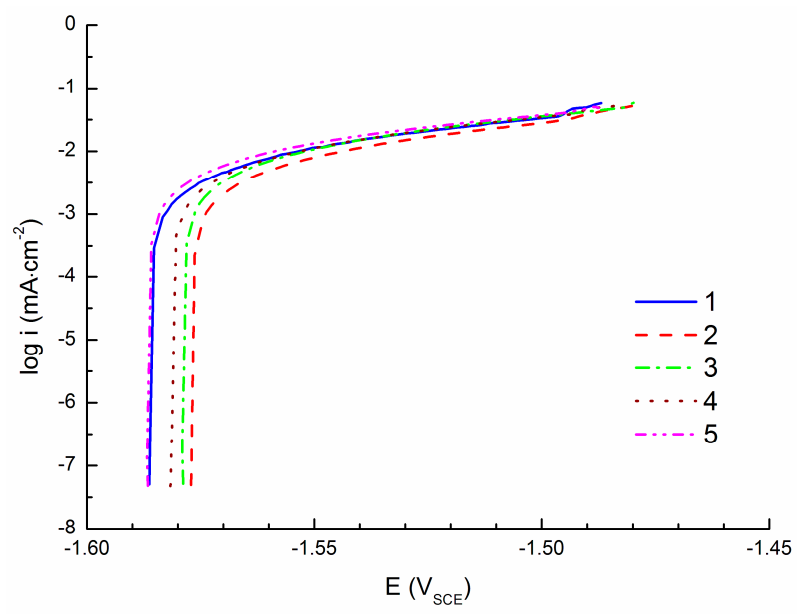

Figure 4. Anodic polarization curves (APCs) of AZ91 tested in $0.1 \mathrm{M} \mathrm{NaCl}$ solution; $+100 \mathrm{mV}$ vs. EOCP. 
Table 3. Electrochemical characteristics of AZ91 in $0.1 \mathrm{M} \mathrm{NaCl}$ solution determined by anodic polarization.

\begin{tabular}{cccccc}
\hline Sample & $\mathbf{1}$ & $\mathbf{2}$ & $\mathbf{3}$ & $\mathbf{4}$ & $\mathbf{5}$ \\
\hline $\mathrm{E}_{\mathrm{OCP}}(\mathrm{V})$ & -1.586 & -1.577 & -1.579 & -1.582 & -1.587 \\
$\mathrm{E}_{\text {pit }}(\mathrm{V})$ & -1.496 & -1.497 & -1.481 & -1.493 & -1.494 \\
Range of Tafel region $(\mathrm{mV})$ & 40 & 30 & 48 & 39 & 43 \\
$\mathrm{i}_{\text {corr }}\left(\mu \mathrm{A} \cdot \mathrm{cm}^{-2}\right)$ & 7.7 & 7.0 & 8.6 & 8.2 & 8.6 \\
\hline
\end{tabular}

Obtained linear polarization curves, containing cathodic and anodic polarization branches, commonly used for material electrochemical characterization are shown in Figure 5. Corrosion attack in the form of pitting was observed at the anodic branch of the curves. The attack was characterized by an increase of current density which belongs to the value of pitting potential $\left(\mathrm{E}_{\text {pit }}\right)$ [75]. The pitting was observed before the beginning of the Tafel region (between 50 and $100 \mathrm{mV}$ vs. EOCP $[63,64]$ ). Therefore, the Tafel region for these anodic branches of the PCs were insufficient to obtain relevant values of $i_{\text {corr }}$. On the other hand, the Tafel regions in the cathodic branch of PCs were more than $50 \mathrm{mV}$ vs. $\mathrm{E}_{\mathrm{OCP}}$. In such situations only the cathodic part of the curve, in combination with $\mathrm{E}_{\mathrm{corr}}$, for the extrapolation was used. The characteristics obtained from the PCs evaluation are given in Table 4.

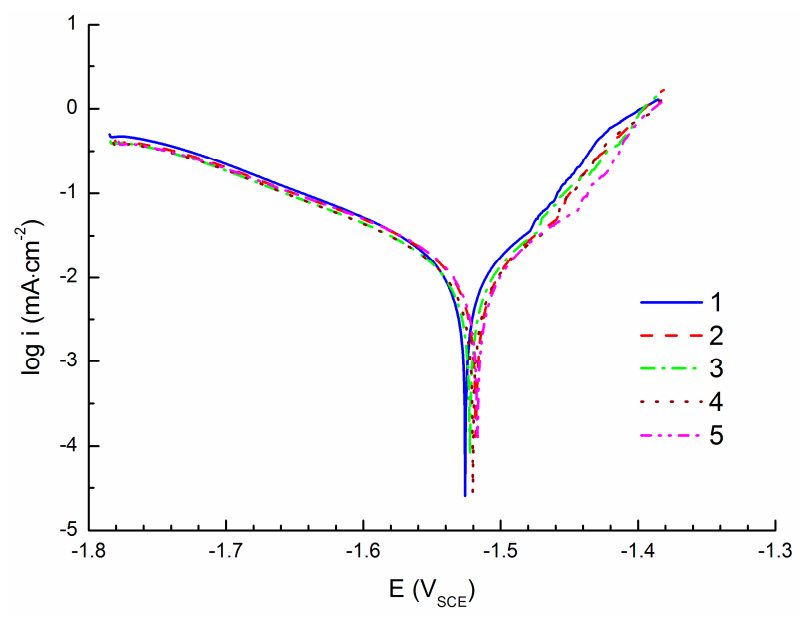

Figure 5. Linear polarization curves (PC) of AZ91 in $0.1 \mathrm{M} \mathrm{NaCl}$ solution containing cathodic and anodic parts; from $-100 \mathrm{mV}$ to $+200 \mathrm{mV}$ vs. EOCP.

Table 4. Electrochemical characteristics of AZ91 tested in $0.1 \mathrm{M} \mathrm{NaCl}$ solution measured by linear polarization curves.

\begin{tabular}{cccccc}
\hline Sample & $\mathbf{1}$ & $\mathbf{2}$ & $\mathbf{3}$ & $\mathbf{4}$ & $\mathbf{5}$ \\
\hline $\mathrm{E}_{\mathrm{OCP}}(\mathrm{V})$ & -1.576 & -1.577 & -1.575 & -1.573 & -1.574 \\
$\mathrm{E}_{\text {corr }}(\mathrm{V})$ & -1.551 & -1.552 & -1.550 & -1.550 & -1.549 \\
$\mathrm{E}_{\text {pit }}(\mathrm{V})$ & -1.511 & -1.518 & -1.524 & -1.522 & -1.515 \\
Range of ACP Tafel region $(\mathrm{mV})$ & -10 & -16 & -24 & -22 & -16 \\
Range of CPC Tafel region $(\mathrm{mV})$ & $>50$ & $>50$ & $>50$ & $>50$ & $>50$ \\
$\mathrm{i}_{\text {corr }}\left(\mu \mathrm{A} \cdot \mathrm{cm}^{-2}\right)$ & 14.9 & 13.4 & 15.1 & 14.9 & 15.0 \\
\hline
\end{tabular}

The average value of $\mathrm{E}_{\mathrm{OCP}}$ determined from PCs was $-1.575 \pm 0.001 \mathrm{~V} ; \mathrm{E}_{\text {corr }}$ was of $-1.550 \pm 0.001 \mathrm{~V}$ and the corrosion current density was of $14.7 \pm 0.6 \mu \mathrm{A} \cdot \mathrm{cm}^{-2}$. 


\section{Discussion}

The microstructure of the cast AZ91 magnesium alloy consists of a solid solution of alloying elements in magnesium in which are randomly distributed AlMn intermetallic phases and intermetallic phases $\mathrm{Mg}_{17} \mathrm{Al}_{12}$ mostly surrounded by areas of $\mathrm{Mg}-\mathrm{Al}$ discontinuous precipitate (Figure 2). Heterogeneity of the microstructure of AZ91 prepared by casting could have an influence on the scatter of the open circuit potential $\mathrm{E}_{\mathrm{OCP}}$ values estimated by polarization techniques. Potential characteristics of $\alpha-\mathrm{Mg}$ areas and present intermetallic phases are different [76], which is a reason for local corrosion attack of the material on their interface due to the creation of a galvanic cell.

Values of the open circuit potential $\mathrm{E}_{\mathrm{OCP}}$ obtained by different polarization methods given in Tables $2-4$ are very similar for all of the curves. This agreement in measured $\mathrm{E}_{\text {corr }}$ values indicates only small influence of the microstructure heterogeneity of individual tested specimens. The area exposed to the corrosion environment with the size of $1.0 \mathrm{~cm}^{2}$ seems to be sufficient to obtain representative data and to consider the microstructure of the experimental material homogenous. Additionally, no significant differences in the values of the corrosion potential determined by Tafel analysis evaluating curves obtained by different polarization methods were determined. However, differences in the obtained values of the corrosion current density $i_{\text {corr }}$ were observed (Table 5). Lower values of $i_{\text {corr }}$ determined by ACP (Table 5) suggest the decrease of the corrosion process rate. This could be explained by the corrosion process evolution and creation of the corrosion products on the specimen surface comparing to the specimens polarized to the cathodic region. Corrosion products, with lower electric conductivity when compared to the magnesium alloy itself, act also like a barrier, which protects the basic material against corrosion environment.

On the other hand, corrosion current density $i_{\text {corr }}$ obtained by polarization of the specimen to the cathodic area have similar values (Table 5) as the values obtained by the linear polarization measurement. In comparison with anodic polarization measurements, the cathodic polarization measurements do not affect the measured surface. Polarization measurements of the cathodic area do not lead to corrosion (respectively, oxidation) of the material. Only reduction of hydrogen, so called hydrogen depolarization, occurs during cathodic polarization and the material surface does not react with the corrosion environment due to the specimen polarization to more negative values than $\mathrm{E}_{\mathrm{OCP}}$. The surface of the material does not react with the $\mathrm{NaCl}$ solution and the creation of a protecting $\mathrm{MgO}$ layer is eliminated.

Table 5. Comparison of polarization techniques of AZ91 tested in $0.1 \mathrm{M} \mathrm{NaCl}$ solution.

\begin{tabular}{cccc}
\hline Technique & $\mathrm{E}_{\mathbf{O C P}}(\mathbf{V})$ & $\mathrm{E}_{\text {corr }}(\mathbf{V})$ & $\mathbf{i}_{\text {corr }}\left(\mu \mathrm{A} \cdot \mathbf{c m}^{-2}\right)$ \\
\hline CPC & $-1.577 \pm 0.011$ & $-1.577 \pm 0.011^{1}$ & $15.4 \pm 1.0$ \\
APC & $-1.582 \pm 0.004$ & $-1.582 \pm 0.004^{1}$ & $8.0 \pm 0.6$ \\
PC & $-1.575 \pm 0.001$ & $-1.550 \pm 0.001$ & $14.7 \pm 0.6$ \\
\hline \multicolumn{4}{c}{${ }^{1} \mathrm{E}_{\text {corr }}$ obtained from $\mathrm{E}_{\mathrm{OCP}}}$.
\end{tabular}

The value of corrosion current density $\mathrm{i}_{\text {corr }}$ obtained by CPC and PC are higher than values obtained by APC due to the direct contact of the specimen and the corrosion environment.

The similarity of the corrosion current densities obtained from PCs and CPCs could also be influenced by the extrapolation of the obtained curves, when mainly cathodic branches of the PCs were used for extrapolation due to the pitting corrosion and subsequently small Tafel region on the anodic branch of the PCs. The range of the Tafel region used for the linear extrapolation of the obtained curves was around $50 \mathrm{mV}$ in the case of CPCs (the exact range from $50 \mathrm{mV}$ from the $\mathrm{E}_{\text {corr }}$ to the value of about $100 \mathrm{mV}$ from $\mathrm{E}_{\mathrm{corr}}$ ). In the case of ACPs the range was from $30-48 \mathrm{mV}$ (the exact range from $50 \mathrm{mV}$ from the $E_{\text {corr }}$ to the value of about $80-98 \mathrm{mV}$ from $E_{\text {corr }}$ ). Evaluation of PCs did not follow the theoretical limit according to the literature in the case of extrapolation of the anodic branch of the curve. In the case of the anodic branch the range for the Tafel extrapolation started at $26-40 \mathrm{mV}$ from $\mathrm{E}_{\text {corr }}$. However, in all of the cases the coefficient of reliability of the line extrapolating the curvilinear 
part reached the minimum value of 0.95 . The determined value of $E_{O C P}$ was considered as $E_{c o r r}$ in the case of CPS and APC curve evaluations.

Polarizing the specimen only to the cathodic or only to the anodic region to obtain $\mathrm{E}_{\mathrm{OCP}}$ can be considered, according to extrapolation shown in Figure 1, as the corrosion potential $\mathrm{E}_{\text {corr }}$. Using different methods of specimen polarization (CPC, APC, and PC), different values of corrosion potential, $\mathrm{E}_{\mathrm{corr}}$, were obtained. Corrosion potentials obtained from CPC and APC have almost the same value, while the value of corrosion potential obtained from PC was shifted to more positive values (Figure 6).

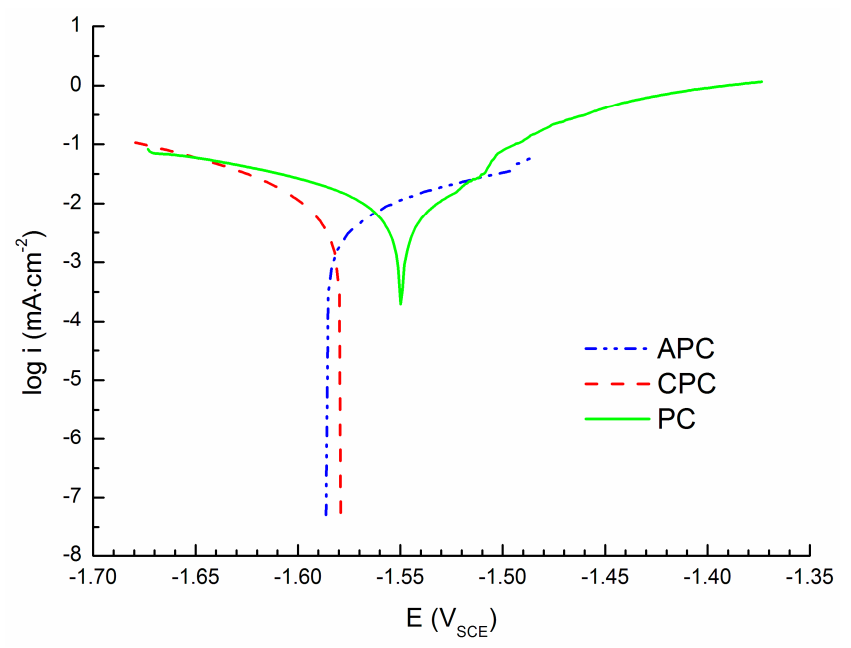

Figure 6. Comparison of polarization techniques of AZ91 in $0.1 \mathrm{M} \mathrm{NaCl}$ solution (CPC, APC, PC).

Figure 7 shows the surface of the AZ91 magnesium alloy after electrochemical measurements. Lighter colored areas on the surface are intermetallic phases and discontinuous precipitate particles present in the microstructure of the alloy (Figure 2). There is no significant corrosion attack observed on the specimen surfaces after cathodic polarization measurements (Figure 7a). Even though a small difference in the determined $\mathrm{E}_{\mathrm{corr}}$ values were observed in the case of the CPC measured specimens, SEM surface analysis did not reveal significant differences in the corrosion attack of individual specimens. The inspected area with a size of $1 \mathrm{~cm}^{2}$ was sufficiently large to allow consideration of the specimen microstructure as homogenous. Specimens measured by anodic polarization (Figure $7 \mathrm{~b}$ ) have corrosion products on their surface. On the specimen surface some localities with higher evolution of corrosion products were present. The areas preferentially attacked by corrosion served as initiation sites for pitting corrosion, which would develop during longer exposition of the material to the $0.1 \mathrm{M}$ $\mathrm{NaCl}$ corrosion environment. The localized corrosion products evolution corresponds to the starting pitting corrosion attack observed on APCs. Significant corrosion occurred during linear polarization (PC) measurements (Figure 7c). Areas attacked by pitting corrosion are already well developed and visible on the specimen surface.

The difference in the corrosion attack of differently polarized specimens can be explained by reactivity of the material. Before each polarization measurement 5 min stabilization was applied. During this period the alloy reacted with the corrosion environment and the specimen surface was affected by formation of the corrosion products. Within the cathodic polarization only hydrogen evolution on the surface was observed. Hydrogen bubbles created on the specimen surface removed corrosion products created on the surface during the stabilization. The specimen surface observed after cathodic polarization did not exhibit any signs of the corrosion attack (Figure 7a). However, in the case of linear polarization, the cleaned specimen surface (with corrosion products removed during the cathodic polarization part) was more reactive during the following anodic polarization part, than the surface of the specimen polarized only to the anodic area, and pitting evolution was observed on the 
specimen surface (Figure 7c). Additionally, not yet developed pitting was observed on the specimen surface in the form of localized areas of corrosion products, which are comparable with areas observed on the surface of the specimen after anodic polarization.

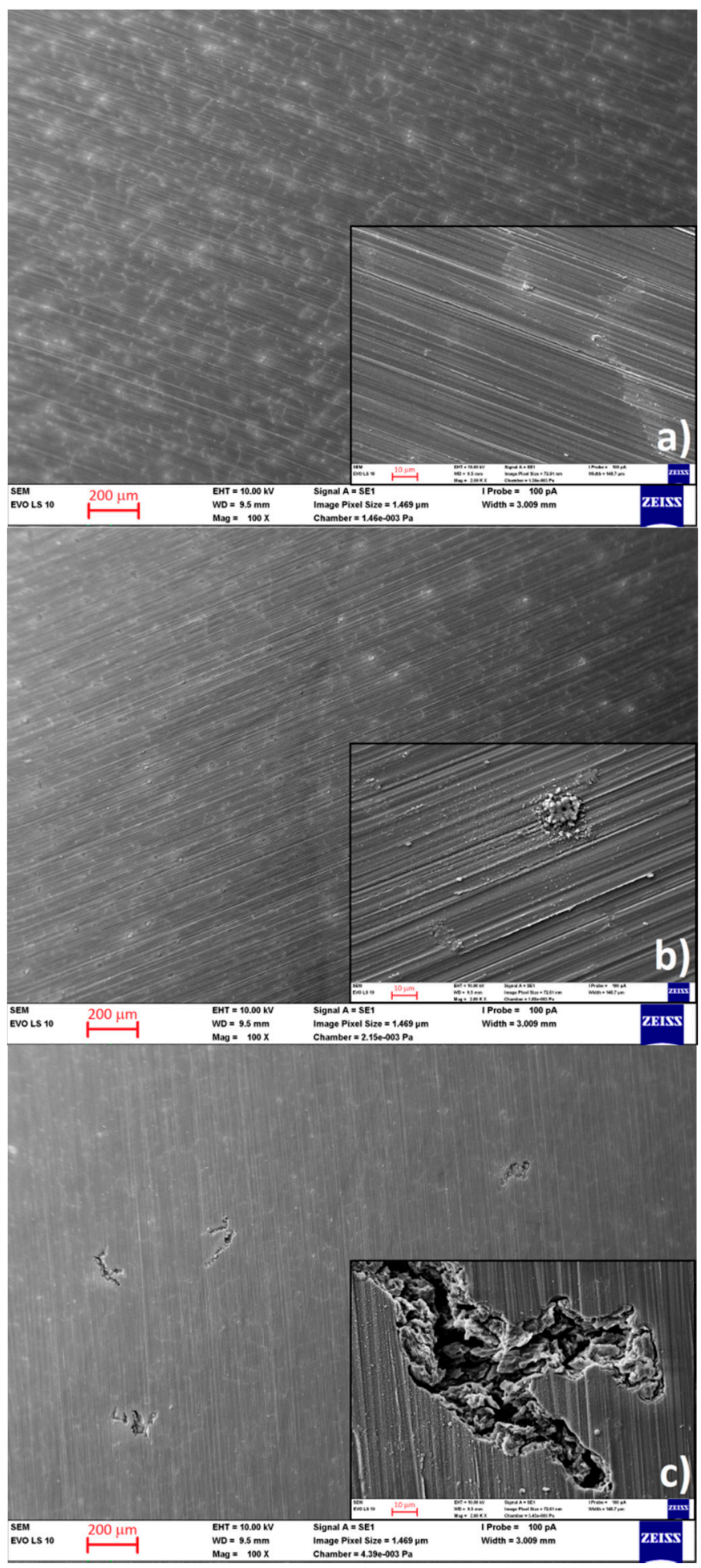

Figure 7. Surface of AZ91 magnesium alloy after electrochemical measurements: (a) cathodic polarization; (b) anodic polarization; and (c) linear polarization. 
Formation of corrosion products on the specimen surface during $5 \mathrm{~min}$ of stabilization before polarization can also explain the differences in $i_{\text {corr }}$. The lowest value of the $i_{\text {corr }}$ in the anodic polarization case could be caused by the oxide layer protecting the specimen surface and slowing the corrosion process of the specimen during the anodic polarization. This protecting layer was, in the case of cathodic polarization and linear polarization (in the cathodic part of the process), removed by hydrogen evolution on the specimen surface.

\section{Conclusions}

This study investigated the effect of using a polarization method on the obtained values of electrochemical characteristics describing the corrosion behavior of cast AZ91 magnesium alloy. The obtained results could be formulated as follows:

1. The microstructure of the examined AZ91 cast magnesium alloy was considered to be homogenous from the macroscopic point of view and homogenous corrosion behavior was observed.

2. Corrosion current density of $\mathrm{i}_{\text {corr }}=15.4 \pm 1.0 \mu \mathrm{A} \cdot \mathrm{cm}^{-2}$ obtained by cathodic polarization is similar to the corrosion current density $i_{\text {corr }}=14.7 \pm 0.6 \mu \mathrm{A} \cdot \mathrm{cm}^{-2}$ obtained by linear polarization. On the other hand, corrosion current density $\mathrm{i}_{\text {corr }}=8.0 \pm 0.6 \mu \mathrm{A} \cdot \mathrm{cm}^{-2}$ obtained by anodic polarization is significantly lower comparing to the previous methods.

3. Corrosion potentials obtained from PC are shifted to more positive values of potential compared to the ACP and CPC.

4. Significant pitting corrosion was observed only in the case of linear polarization measurements. Localized corrosion product areas were observed on PC and APC specimens.

Acknowledgments: This work was supported by the project "Materials Research Centre at FCH BUT-Sustainability and Development", REG LO1211, with financial support from National Programme for Sustainability I (Ministry of Education, Youth and Sports), Czech Republic.

Author Contributions: Jakub Tkacz and Jaromír Wasserbauer conceived and designed the experiments; Jakub Tkacz and Jozef Minda performed electrochemical measurements; Jakub Tkacz performed SEM analysis; Jakub Tkacz and Stanislava Fintová wrote the paper.

Conflicts of Interest: The authors declare no conflict of interest.

\section{References}

1. Cui, Z.; Li, X.; Xiao, K.; Dong, C. Atmospheric corrosion of field-exposed AZ31 magnesium in a tropical marine environment. Corros. Sci. 2013, 76, 243-256. [CrossRef]

2. Jian, S.Y.; Chu, Y.R.; Lin, C.S. Permanganate conversion coating on AZ31 magnesium alloys with enhanced corrosion resistance. Corros. Sci. 2015, 93, 301-309. [CrossRef]

3. Tkacz, J.; Němcová, A.; Zmrzlý, M.; Pacal, B. Improvement of corrosion resistance of AZ61 magnesium alloy. Koroze Ochr. Mater. 2013, 56, 100-103.

4. Kulecki, M.K. Magnesium and its alloys applications in automotive industry. Int. J. Adv. Manuf. Technol. 2008, 39, 851-865.

5. Mordike, B.L.; Ebert, T. Magnesium: Properties-applications-potential. Mater. Sci. Eng. A 2001, 302, 37-45. [CrossRef]

6. Friedrich, H.; Schumann, S. Research for a "new age of magnesium" in the automotive industry. J. Mater. Process. Technol. 2001, 117, 276-281. [CrossRef]

7. Gray, J.E.; Luan, B. Protective coatings on magnesium and its alloys-A critical review. J. Alloys Compd. 2002, 336, 88-113. [CrossRef]

8. Zhang, J.; $\mathrm{Wu}, \mathrm{C}$. Corrosion and Protection of Magnesium Alloys-A Review of the Patent Literature. Recent Pat. Corros. Sci. 2010, 2, 55-64. [CrossRef]

9. Mousa, H.M.; Hussein, K.H.; Woo, H.M.; Park, C.H.; Kim, C.S. One-step anodization deposition of anticorrosive bioceramic compounds on AZ31B magnesium alloy for biomedical application. Ceram. Int. 2015, 61, 10861-10870. [CrossRef] 
10. Witte, F.; Kaese, V.; Haferkamp, H.; Switzer, E.; Meyer-Lindenberg, A.; Wirth, C.J.; Windhagen, H. In vivo corrosion of four magnesium alloys and the associated bone response. Biomaterials 2005, 26, 3557-3563. [CrossRef] [PubMed]

11. Zhai, Z.; Qu, X.; Li, H.; Yang, K.; Wan, P.; Tan, L.; Ouyang, Z.; Liu, X.; Tian, B.; Xiao, F.; et al. The effect of metallic magnesium degradation products on osteoclast-induced osteolysis and attenuation of NF- $\mathrm{KB}$ and NFATc1 signaling. Biomaterials 2014, 35, 6299-6310. [CrossRef] [PubMed]

12. Amaravathy, P.; Sathyanarayanan, S.; Sowndarya, S.; Rajendran, N. Bioactive HA/TiO 2 coating on magnesium alloy for biomedical applications. Ceram. Int. 2014, 40, 6617-6630. [CrossRef]

13. Razavi, M.; Fathi, M.; Savabi, O.; Razavi, S.M.; Beni, B.H.; Vashaee, D.; Tayebi, L. Controlling the degradation rate of bioactive magnesium implants by electrophoretic deposition of akermanite coating. Ceram. Int. 2014, 40, 3865-3872. [CrossRef]

14. Wu, F.; Wei, J.; Guo, H.; Chen, F.; Hong, H.; Liu, C. Self-setting bioactive calcium-magnesium phosphate cement with high strength and degradability for bone regeneration. Acta Biomater. 2008, 4, 1873-1884. [CrossRef] [PubMed]

15. Huang, Y.; Jin, X.; Zhang, X.; Sun, H.; Tu, J.; Tang, T.; Chang, J.; Dai, K. In vitro and in vivo evaluation of akermanite bioceramics for bone regeneration. Biomaterials 2009, 30, 5041-5048. [CrossRef] [PubMed]

16. Barchiche, C.E.; Rocca, E.; Juers, C.; Hazan, J.; Steinmetz, J. Corrosion resistance of plasma-anodized AZ91D magnesium alloy by electrochemical methods. Electrochim. Acta 2007, 53, 417-425. [CrossRef]

17. Ardelean, H.; Frateur, I.; Zanna, S.; Atrens, A.; Marcus, P. Corrosion protection of AZ91 magnesium alloy by anodizing in niobium and zirconium-containing electrolytes. Corros. Sci. 2009, 51, 3030-3038. [CrossRef]

18. Lin, X.; Wang, X.; Tan, L.; Wan, P.; Yu, X.; Li, Q.; Yang, K. Effect of preparation parameters on the properties of hydroxyapatite containing micro-arc oxidation coating on biodegradable ZK60 magnesium alloy. Ceram. Int. 2014, 40, 10043-10051. [CrossRef]

19. Hiromoto, S.; Inoue, M.; Taguchi, T.; Yamane, M.; Ohtsu, N. In vitro and in vivo biocompatibility and corrosion behaviour of a bioabsorbable magnesium alloy coated with octacalcium phosphate and hydroxyapatite. Acta Biomater. 2015, 11, 520-530. [CrossRef] [PubMed]

20. Heublein, B.; Rohde, R.; Kaese, V.; Niemeyer, M.; Hartung, W.; Haverich, A. Biocorrosion of magnesium alloys: A new principle in cardiovascular implant technology? Heart 2003, 89, 651-656. [CrossRef] [PubMed]

21. Staiger, M.P.; Pietak, A.M.; Huadmai, J.; Dias, G. Magnesium and its alloys as orthopedic biomaterials: A review. Biomaterials 2006, 27, 1728-1734. [CrossRef] [PubMed]

22. Witte, F.; Calliess, T.; Windhagen, H. Degradable synthetische Implantatmaterialien. Orthopäde 2008, 37, 125-130. [CrossRef] [PubMed]

23. Zeng, R.; Dietzel, W.; Witte, F.; Hort, N.; Blawert, C. Progress and Challenge for Magnesium Alloys as Biomaterials. Adv. Eng. Mater. 2008, 10, B3-B14. [CrossRef]

24. Witte, F. The history of biodegradable magnesium implants: A review. Acta Biomater. 2010, 6, 1680-1692. [CrossRef] [PubMed]

25. Waksman, R.; Pakala, R. Biodegradable and Bioabsorbable Stents. Curr. Pharm. Des. 2010, 16, 4041-4051. [CrossRef] [PubMed]

26. Zartner, P.; Buettner, M.; Singer, H.; Sigler, M. First biodegradable metal stent in a child with congenital heart disease: Evaluation of macro and histopathology. Catheter. Cardiovasc. Interv. 2007, 69, 443-446. [CrossRef] [PubMed]

27. Erbel, R.; Mario, C.D.; Bartunek, J.; Bonnier, J.; Bruyne, B.D.; Eberli, F.R.; Erne, P.; Haude, M.; Heublein, B.; Horrigan, M.; et al. Temporary scaffolding of coronary arteries with bioabsorbable magnesium stents: A prospective, non-randomised multicentre trial. Lancet 2007, 369, 1869-1875. [CrossRef]

28. Haude, M.; Erbel, R.; Varheye, S.; Degen, H.; Böse, D.; Vermeersch, P.; Wijnbergen, I.; Wiessman, N.; Prati, F.; Waksman, R.; et al. Safety and performance of the drug-eluting absorbable metal scaffold (DREAMS) in patients with de-novo coronary lesions: 12 month results of the prospective, multicentre, first-in-man BIOSOLVE-I trial. Lancet 2013, 381, 836-844. [CrossRef]

29. Harrison, R.; Maradze, D.; Lyons, S.; Zheng, Y.; Liu, Y. Corrosion of magnesium and magnesium-calcium alloy in biologically-simulated environment. Prog. Nat. Sci. 2014, 24, 539-546. [CrossRef]

30. Kirkland, N.T.; Birbilis, N.; Staiger, M.P. Assessing the corrosion of biodegradable magnesium implants: A critical review of current methodologies and their limitations. Acta Biomater. 2012, 8, 925-936. [CrossRef] [PubMed] 
31. Oyen, M.L.; Ferguson, V.L.; Bembey, A.K.; Bushby, A.J.; Boyde, A. Composite bounds on the elastic modulus of bone. J. Biomech. 2008, 41, 2585-2588. [CrossRef] [PubMed]

32. Rho, J.Y.; Ashman, R.B.; Turner, C.H. Young's modulus of trabecular and cortical bone material: Ultrasonic and microtensile measurements. J. Biomech. 1993, 26, 111-119. [CrossRef]

33. Castellani, C.; Lindtner, R.A.; Hausbrandt, P.; Tschegg, E.; Stanzl-Tschegg, S.E.; Zanoni, G.; Beck, S.; Weinberg, A.M. Bone-implant interface strength and osseointegration: Biodegradable magnesium alloy versus standard titanium control. Acta Biomater. 2011, 7, 432-440. [CrossRef] [PubMed]

34. Witte, F.; Feyerabend, F.; Maier, P.; Fischer, J.; Störmer, M.; Blawert, C.; Dietzel, W.; Hort, N. Biodegradable magnesium-hydroxyapatite metal matrix composites. Biomaterials 2007, 28, 2163-2174. [CrossRef] [PubMed]

35. Waizy, H.; Seitz, J.M.; Reifenrath, J.; Weizbauer, A.; Bach, F.W.; Meyer-Lindenberg, A.; Denkena, B.; Windhagen, H. Biodegradable magnesium implants for orthopedic applications. J. Mater. Sci. 2013, 48, 39-50. [CrossRef]

36. Grubbs, R.D.; Maguire, M.E. Magnesium as a regulatory cation: Criteria and evaluation. Magnesium 1987, 6, 113-127. [PubMed]

37. Beyenbach, K.W. Transport of magnesium across biological membranes. Magnes. Trace Elem. 1990, 9, $223-254$.

38. Saris, N.E.L.; Mervaala, E.; Karppanen, H.; Khawaja, J.A.; Lewenstam, A. Magnesium: An update on physiological, clinical and analytical aspects. Clin. Chim. Acta 2000, 294, 1-26. [CrossRef]

39. Wacker, W.E.C.; Parisi, A.F. Magnesium metabolism. Med. Prog. 1968, 278, 772-776.

40. Flatman, P.W. Mechanisms of Magnesium Transport. Physiology 1991, 53, 359-371. [CrossRef] [PubMed]

41. Romani, A.M.; Scarpa, A. Regulation of cellular magnesium. Front. Biosci. 2000, 5, D720-D734. [CrossRef] [PubMed]

42. Agus, Z.S.; Morad, M. Modulation of Cardiac ION Channels by Magnesium. Physiology 1991, 53, $299-307$. [CrossRef] [PubMed]

43. Song, G. Control of biodegradation of biocompatable magnesium alloys. Corros. Sci. 2007, 49, $1696-1701$. [CrossRef]

44. Hong, D.; Saha, P.; Chou, D.T.; Lee, B.; Collins, B.E.; Tan, Z.; Dong, Z.; Kumta, P.N. In vitro degradation and cytotoxicity response of $\mathrm{Mg}-4 \% \mathrm{Zn}-0.5 \% \mathrm{Zr}$ (ZK40) alloy as a potential biodegradable material. Acta Biomater. 2013, 9, 8534-8547. [CrossRef] [PubMed]

45. Johnson, I.; Liu, H. A Study on Factors Affecting the Degradation of Magnesium and a Magnesium-Yttrium Alloy for Biomedical Applications. PLoS ONE 2013, 8, e65603. [CrossRef] [PubMed]

46. Guan, R.G.; Johnson, I.; Cui, T.; Zhao, T.; Zhao, Z.Y.; Li, X.; Liu, H. Electrodeposition of hydroxyapatite coating on $\mathrm{Mg}-4.0 \mathrm{Zn}-1.0 \mathrm{Ca}-0.6 \mathrm{Zr}$ alloy and in vitro evaluation of degradation, hemolysis, and cytotoxicity. J. Biomed. Mater. Res. Part A 2012, 100, 999-1015. [CrossRef] [PubMed]

47. Liu, $\mathrm{H}$. The effects of surface and biomolecules on magnesium degradation and mesenchymal stem cell adhesion. J. Biomed. Mater. Res. Part A 2011, 99, 249-260. [CrossRef] [PubMed]

48. Birbilis, N.; Williams, G.; Gusieva, K.; Samaniego, A.; Gibson, M.A.; McMurray, H.N. Poisoning the corrosion of magnesium. Electrochem. Commun. 2013, 34, 295-298. [CrossRef]

49. Hadzima, B.; Mhaede, M.; Pastorek, F. Electrochemical characteristics of calcium-phosphatized AZ31 magnesium alloy in $0.9 \% \mathrm{NaCl}$ solution. J. Mater. Sci. Mater. Med. 2014, 25, 1217-1237. [CrossRef] [PubMed]

50. Altun, H.; Sen, S. The effect of PVD coatings on the corrosion behaviour of AZ91 magnesium alloy. Mater. Des. 2006, 27, 1174-1179. [CrossRef]

51. Wu, C.S.; Zhang, Z.; Cao, F.H.; Zhang, L.J.; Zhang, J.Q.; Cao, C.N. Study on the anodizing of AZ31 magnesium alloys in alkaline borate solutions. Appl. Surf. Sci. 2007, 253, 3893-3898. [CrossRef]

52. Chai, L.; Yu, X.; Yang, Z.; Wang, Y.; Okido, M. Anodizing of magnesium alloy AZ31 in alkaline solutions with silicate under continuous sparking. Corros. Sci. 2008, 50, 3274-3279. [CrossRef]

53. Brusciotti, F.; Snihirova, D.V.; Xue, H.; Montemor, M.F.; Lamaka, S.V.; Ferreira, M.G.S. Hybrid epoxy-silane coatings for improved corrosion protection of Mg alloy. Corros. Sci. 2008, 67, 82-90. [CrossRef]

54. Lamaka, S.V.; Montemor, M.F.; Galio, A.F.; Zheludkevich, M.L.; Trindade, C.; Dick, L.F.; Ferreira, M.G.S. Novel hybrid sol-gel coatings for corrosion protection of AZ31B magnesium alloy. Electrochim. Acta 2007, 53, 4773-4783. [CrossRef]

55. Montemor, M.F.; Trabelsi, W.; Lamaka, S.V.; Yasakau, K.A.; Zheludkevich, M.L.; Bastos, A.C.; Ferreira, M.G.S. The synergistic combination of bis-silane and $\mathrm{CeO}_{2} \cdot \mathrm{ZrO}_{2}$ nanoparticles on the electrochemical behaviour of galvanised steel in $\mathrm{NaCl}$ solutions. Electrochim. Acta 2008, 53, 5913-5922. [CrossRef] 
56. Wang, J.; Li, Y.; Huang, S.; Zhou, X. Study of the corrosion behavior and the corrosion films formed on the surfaces of Mg-xSn alloys in 3.5 wt. \% NaCl solution. Appl. Surf. Sci. 2014, 317, 1143-1150. [CrossRef]

57. Arrabal, R.; Pardo, A.; Merino, M.C.; Mohedano, M.; Casajús, P.; Paucar, K.; Garcés, G. Effect of Nd on the corrosion behaviour of AM50 and AZ91D magnesium alloys in 3.5 wt. \% NaCl solution. Corros. Sci. 2012, 55, 301-312. [CrossRef]

58. Rosalbino, F.; Angelini, E.; Negri, S.D.; Saccone, A.; Delfino, S. Effect of erbium addition on the corrosion behaviour of $\mathrm{Mg}-\mathrm{Al}$ alloys. Intermetallics 2005, 13, 55-60. [CrossRef]

59. Zhang, J.; Niu, X.; Qiu, X.; Liu, K.; Nan, C.; Tang, D.; Meng, J. Effect of yttrium-rich misch metal on the microstructures, mechanical properties and corrosion behavior of die cast AZ91 alloy. J. Alloys Compd. 2009, 471, 322-330. [CrossRef]

60. Zhou, X.; Huang, Y.; Wei, Z.; Chen, Q.; Gan, F. Improvement of corrosion resistance of AZ91D magnesium alloy by holmium addition. Corros. Sci. 2006, 46, 4223-4233. [CrossRef]

61. Chu, P.W.; Marquis, E.A. Linking the microstructure of a heat-treated WE43 Mg alloy with its corrosion behavior. Corros. Sci. 2015, 101, 94-104. [CrossRef]

62. Gusieva, K.; Davies, C.H.J.; Scully, J.R.; Birbilis, N. Corrosion of magnesium alloys: The role of alloying. Int. Mater. Rev. 2014, 60, 169-194. [CrossRef]

63. Song, D.; Ma, A.B.; Jiang, J.H.; Lin, P.H.; Yang, D.H.; Fan, J.F. Corrosion behaviour of bulk ultra-fine grained AZ91D magnesium alloy fabricated by equal-channel angular pressing. Corros. Sci. 2011, 53, 362-373. [CrossRef]

64. Pardo, A.; Merino, M.C.; Coy, A.E.; Arrabal, R.; Viejo, F.; Matykina, E. Corrosion behaviour of magnesium/aluminium alloys in 3.5 wt. \% NaCl. Corros. Sci. 2008, 50, 823-834. [CrossRef]

65. Kim, H.S.; Kim, W.J. Enhanced corrosion resistance of ultrafine-grained AZ61 alloy containingvery fine particles of $\mathrm{Mg}_{17} \mathrm{Al}_{12}$ phase. Corros. Sci. 2013, 75, 228-238. [CrossRef]

66. Ambat, R.; Aung, N.N.; Zhou, W. Evaluation of microstructural effects on corrosion behaviour of AZ91D magnesium alloy. Corros. Sci. 2013, 42, 1433-1455. [CrossRef]

67. Hadzima, B.; Janeček, M.; Suchý, P.; Müller, J.; Wagner, L. Microstructure and Corrosion Properties of Fine-Grained Mg-Based Alloys. Mater. Sci. Forum 2008, 584-586, 994-999. [CrossRef]

68. Pardo, A.; Feliu, S., Jr.; Merino, M.C.; Arrabal, R.; Matykina, E. Electrochemical Estimation of the Corrosion Rate of Magnesium/Aluminium Alloys. Int. J. Corros. 2010, 2010, 953850. [CrossRef]

69. King, A.D.; Birbilis, N.; Scully, J.R. Accurate Electrochemical Measurement of Magnesium Corrosion Rates; a Combined Impedance, Mass-Loss and Hydrogen Collection Study. Electrochim. Acta 2014, 121, 394-406. [CrossRef]

70. Fontana, M.G. Corrosion Engineering, 3rd ed.; McGraw-Hill: New York, NY, USA, 1986.

71. Stansbury, E.; Buchanan, R. Fundamentals of Electrochemical Corrosion, 1st ed.; ASM International: Materials Park, OH, USA, 2000.

72. Kubatík, T.F.; Pala, Z.; Neufuss, K.; Vilémová, M.; Mušálek, R.; Stoulil, J.; Slepička, P.; Chráska, T. Metallurgical bond between magnesium AZ91 alloy and aluminium plasma sprayed coatings. Surf. Coat. Technol. 2015, 282, 163-170. [CrossRef]

73. Geckili, O.; Bilhan, H.; Bilgin, T.; Anthony von Fraunhofer, J. The effect of urea on the corrosion behavior of different dental alloys. Indian J. Dent. Res. 2012, 23, 75-79. [CrossRef] [PubMed]

74. Ha, H.-Y.; Kim, H.J.; Baek, S.-M.; Kim, B.; Sohn, S.-D.; Shin, H.-J.; Jeong, H.Y.; Park, S.H.; Yim, C.D.; You, B.S.; et al. Improved corrosion resistance of extruded $\mathrm{Mg}-8 \mathrm{Sn}-1 \mathrm{Zn}-1 \mathrm{Al}$ alloy by microalloying with Mn. Scr. Mater. 2015, 109, 38-43. [CrossRef]

75. Gu, C.D.; Yan, W.; Zhang, J.L.; Tu, J.P. Corrosion resistance of AZ31B magnesium alloy with a conversion coating produced from a choline chloride-Urea based deep eutectic solvent. Corros. Sci. 2016, 106, 108-116. [CrossRef]

76. Coy, A.E.; Viejo, F.; Garcia-Garcia, F.J.; Liu, Z.; Skeldon, P.; Thompson, G.E. Effect of excimer laser surface melting on the microstructure and corrosion performance of the die cast AZ91D magnesium alloy. Corros. Sci. 2010, 52, 387-397. [CrossRef]

(C) 2016 by the authors; licensee MDPI, Basel, Switzerland. This article is an open access article distributed under the terms and conditions of the Creative Commons Attribution (CC-BY) license (http://creativecommons.org/licenses/by/4.0/). 